\title{
Edukacja ekologiczna w Drugiej Rzeczypospolitej inspiracją dla praktyki edukacyjnej w XXI wieku*
}

\begin{abstract}
Environmental education in the Second Polish Republic for educational practice in the 21 st century.

This article explains how environmental awareness was raised among primary school pupils in the Second Polish Republic illustrated with an example of "Nasi Przyjaciele" magazine, published by the Society for Protection and Care of Animals in Krakow. The monthly was recommended by the Ministry of Religious Denominations and Public Enlightment for school use. In the specific sections of the magazine, environmental attitudes were promoted by means of articles, appeals to provide environmental education, environmental protection and, last but not least, children's practical activities as part of the Young Friends of Animals Circle, contests for pupils of elementary schools and their creative co-participation in editing the magazine (stories and poems written by the children were published as the winning contest works). The editors regularly provided answers to children's questions about care of animals and environmental protection.
\end{abstract}

Keywords: history of education, national cultural heritage, the Second Polish Republic (1918-1939), environmental education, "Nasi Przyjaciele" (1937-1939), raising children's environmental awareness.

W procesie kształtowania postaw ekologicznych uczniów szkół powszechnych i średnich ogólnokształcących w okresie Drugiej Rzeczypospolitej ogromną funkcję pełniły periodyki, które Ministerstwo Wyznań Religijnych i Oświecenia Publicznego rekomendowało do użytku szkolnego. Wśród tytułów z kwalifikacją do bibliotek uczniowskich w szkołach powszechnych należy wymienić czasopismo „Nasi Przyjaciele” (Nr II Pr-16402/38)1.

\footnotetext{
* Tekst opublikowano także w: Z badań nad tradycja polskiej pedagogiki, t. II. Księga jubileuszowa dedykowana Profesor Danucie Koźmian, pod red. E. Magiery i J. Król, Szczecin 2016, s. 477-490.

1 Por. Komunikat o wydawnictwach. A. 8. Czasopisma do bibliotek uczniowskich, w: Dziennik Urzędowy Ministerstwa Wyznań Religijnych i Oświecenia Publicznego, Warszawa 1939, nr 5 (z 18 lipca 1939 r.), poz. 340 , s. 342 .
} 
Celem artykułu jest wyjaśnienie, jak kształtowano postawy ekologiczne dzieci na łamach tego miesięcznika (kryterium problemowe). W związku z tym, podstawę źródłową stanowi periodyk „Nasi Przyjaciele” (1937-1939) oraz Dziennik Urzędowy Ministerstwa Wyznań Religijnych i Oświecenia Publicznego (1918-1939).

\section{Działalność praktyczna w kółkach młodych przyjaciół zwierząt}

Redaktorzy miesięcznika „Nasi Przyjaciele”2 (wydawanego od listopada 1937 r. nakładem Związku Opieki nad Zwierzętami w Krakowie ${ }^{3}$ ), doceniając zaangażowanie poznawcze, emocjonalne i aplikacyjne dzieci w zakresie ochrony przyrody, zwrócili się do nich z prośbą o twórczy współudział ${ }^{4} \mathrm{w}$ redagowaniu periodyku. Wyjaśniono, że uczennice i uczniowie, pragnący należeć do Kółka Młodych Przyjaciół Zwierząt powinni poprosić swego opiekuna klasowego, aby zgłosił je do Związku Opieki nad Zwierzętami w Krakowie. W pierwszym numerze (zeszycie) miesięcznika opublikowano Regulamin Kółek Młodych Przyjaciół Zwierząt, w którym określono, że celem Kółek jest niesienie pomocy i roztaczanie opieki nad zwierzętami chorymi, opuszczonymi, krzywdzonymi oraz pogłębianie wiedzy o zwierzętach i szerzenie jej wśród koleżanek, kolegów. Członkiem Kółka mógł zostać uczeń (uczennica), uczęszczający (uczęszczająca) do klasy IV lub V szkoły powszechnej - po pisemnym przyrzeczeniu na legitymacji Młodych Przyjaciół Zwierząt, że zawsze będzie się dobrze obchodzić ze zwierzętami. Podczas posiedzeń Kółek Młodych Przyjaciół Zwierząt (które odbywały się co najmniej raz w miesiącu) wygłaszano referaty, pogadanki, oglądano filmy, przezrocza, ilustracje o tematyce przyrodniczej i ochrony przyrody. Omawiano również wszelkie sprawy bieżące dotyczące działalności danego kółka5 .

Należy zaznaczyć, że w dziale „Kronika” analizowanego miesięcznika systematycznie umieszczano informacje o Kółkach Młodych Przyjaciół Zwierząt, które działały w wielu szkołach, m.in. w Szkole Powszechnej im. św. Jana Kantego w Krakowie, w Szkole Powszechnej im. Klementyny Tańskiej w Krakowie ${ }^{6}$, w Szkole Powszechnej Instytutu Marii w Krakowie (pod kierunkiem siostry Awilii), Szkole Powszechnej nr 9 im.

\footnotetext{
${ }^{2}$ Redaktor odpowiedzialny: Kazimiera Treterowa (Związek Opieki nad Zwierzętami w Krakowie). Komitet redakcyjny: Feliks Bursa (wizytator szkół, Kuratorium Okręgu Szkolnego Krakowskiego), dr Marian Cichocki (inspektor szkolny), Eugeniusz Frączek (inspektor szkolny), dr Antoni Górny (inspektor szkolny), Witold Zechenter (Związek Opieki nad Zwierzętami w Krakowie).

3 Adres redakcji: Związek Opieki nad Zwierzętami, Kraków, ul. Zwierzyniecka 42 (tel. 110-10).

${ }^{4}$ Por. „Nasi Przyjaciele” 1937 (rok 1), nr 1 (listopad 1937), Nakładem Związku Opieki nad Zwierzętami w Krakowie, s. 1.

${ }^{5}$ Por. Regulamin Kótek Młodych Przyjaciót Zwierząt, „Nasi Przyjaciele” 1937 (rok 1), nr 1 (listopad 1937), Nakładem Związku Opieki nad Zwierzętami w Krakowie, s. 6.

6 Por. „Kronika”, „Nasi Przyjaciele” 1937 (rok 1), nr 2 (grudzień 1937), Nakładem Związku Opieki nad Zwierzętami w Krakowie, s. 7.
} 
Stanisława Konarskiego w Krakowie ${ }^{7}$ oraz w wielu innych (nawet w szkołach jednoklasowych, działających w małych miejscowościach ${ }^{8}$ ) w województwie krakowskim, w których działały również Sekcje Ochrony Przyrody Spółdzielni Uczniowskiej. Informowano o aktywnej pomocy uczniów szkół powszechnych w zbiórce darów pieniężnych na cele Ambulatorium i Lecznicy Związku Opieki nad Zwierzętami w Krakowie ${ }^{10}$ oraz o odczytach i pogadankach z przezroczami, takich jak np. Stanisława Bełżyńskiego (12 listopada 1938 r.), w którym udział wzięli członkowie wielu Kółek Młodych Przyjaciół Zwierząt ${ }^{11}$.

W miesięczniku „Nasi Przyjaciele” dominowała problematyka przyrodnicza oraz dotycząca działalności praktycznej na rzecz ochrony przyrody, informowano czytelników o obchodzonym 4 października „Święcie Patrona Zwierząt” (św. Franciszka z Asyżu $\left.{ }^{12}\right)^{13}$ oraz „Dniu Dobroci dla Zwierząt” - zorganizowanym przez Związek Opieki nad Zwierzętami wiosną 1938 i 1939 r. ${ }^{14} \mathrm{~W}$ związku z tym świętem opublikowano harmonogram obchodów $^{15}$, które zrealizowano 21 maja 1939 r. ${ }^{16}$ Następnie opublikowano sprawozdanie z obchodów i w ten sposób poinformowano czytelników miesięcznika „Nasi Przyjaciele" o przebiegu tego święta - m.in. o wystawie prac członków Kółek Młodych Przyrodników, pochodzie młodzieży z czworonożnymi ulubieńcami oraz przedstawicieli Służby Łączności Armii z psami, gołębiami, końmi, psami policyjnymi oraz końmi roboczymi, odczycie przez radio Zygmunta Nowakowskiego - prezesa Związku Opieki nad

7 Por. „Kronika”, „Nasi Przyjaciele” 1938 (rok 2), nr 11 (listopad 1938), Nakładem Związku Opieki nad Zwierzętami w Krakowie, s. 8.

8 „Kronika”, „Nasi Przyjaciele” 1938 (rok 2), nr 4 (luty 1938), Nakładem Związku Opieki nad Zwierzętami w Krakowie, s. 8.

9 Por. „Kronika”, „Nasi Przyjaciele” 1938 (rok 2), nr 3 (styczeń 1938), Nakładem Związku Opieki nad Zwierzętami w Krakowie, s. 7.

10 Por. „Kronika”, „Nasi Przyjaciele” 1938 (rok 2), nr 6 (kwiecień 1938), Nakładem Związku Opieki nad Zwierzętami w Krakowie, s. 7.

11 Por. „Kronika”, „Nasi Przyjaciele” 1938 (rok 2), nr 12 (grudzień 1938), Nakładem Związku Opieki nad Zwierzętami w Krakowie, s. 7.

${ }^{12} \mathrm{Na}$ łamach miesięcznika poinformowano czytelników, że to święto jest obchodzone również w innych krajach, m.in. w Hrabstwie Susex w Anglii - biorą w nim udział dzieci, które przyprowadzają swoje ulubione zwierzęta. Por. „Kronika”, „Nasi Przyjaciele” 1939 (rok 3), nr 4 (kwiecień 1939), Nakładem Związku Opieki nad Zwierzętami w Krakowie, s. 5.

13 „Nasi Przyjaciele” 1938 (rok 2), nr 10 (październik 1938), Nakładem Związku Opieki nad Zwierzętami w Krakowie, s. 1.

14 Por. „Nasi Przyjaciele” 1939 (rok 3), nr 3 (marzec 1939), Nakładem Związku Opieki nad Zwierzętami w Krakowie, s. 1.

15 Harmonogram Dnia Dobroci dla Zwierzat (w II połowie maja 1939 roku): 1) Pogadanka radiowa w przededniu uroczystości 2) Pochód ze zwierzętami i z transparentami poprzedzony msza święta 3) Wystawa międzyszkolna, urządzona staraniem opiekunów Kółek Młodych Przyjaciól Zwierząt (na która należało przygotować następująe eksponaty: gniazda sztuczne, karmniki rozmaitego typu, manuskrypty pogadanek i odczytów, wycinki prasowe oprawione w albumy, afisze reklamowe, transparenty, fotografie, gazetki ścienne, tablice szkolne Związu Opieki nad Zwierzętami itp.) 4) Uroczyste rozdanie nagród członkom Kótek Młodych Przyjaciół Zwierząt za udział w ankiecie, połaczone z porankiem w szkole. Por. „Nasi Przyjaciele” 1939 (rok 3), nr 4 (kwiecień 1939), Nakładem Związku Opieki nad Zwierzętami w Krakowie, s. 4.

16 „Nasi Przyjaciele” 1939 (rok 3), nr 5 (maj 1939), Nakładem Związku Opieki nad Zwierzętami w Krakowie, s. 7. 
Zwierzętami na temat „Zwierzę, sojusznik człowieka na wojnie”17. Zaprezentowano wyjątki z audycji radiowej poprzedzającej tę uroczystość pt. Dlaczego urządzamy Dzień Dobroci dla Zwierząt? wraz z kilkoma wypowiedziami na ten temat uczniów szkół powszechnych (kl. IV, V, VI) ${ }^{18}$, umieszczono również w miesięczniku zdjęcie z pochodu w Dniu Dobroci dla Zwierząt w Krakowie (21 maja 1939 r.) ${ }^{19}$.

Poza tym na łamach miesięcznika zwracano się z prośbą do młodych czytelników o opiekę nad znalezionymi psami ${ }^{20}$ oraz dokarmianie zwierząt zimą ${ }^{21}$, budowanie karmników okiennych dla ptaków (na parapecie), karmników heskich (wolno stojących w ogrodzie, parku), niesienie pomocy zwierzętom ${ }^{22}$. Opisywano wskazówki prawidłowego obsługiwania karmników ${ }^{23}$ oraz dotyczące opieki nad znalezionymi zwierzętami ${ }^{24}$, zalecano dzieciom obserwowanie ptaków i innych zwierząt ${ }^{25}$. Wyjaśniano, co uczniowie szkół powszechnych mogą uczynić dobrego dla zwierząt ${ }^{26}$, pisano o dzielnych zwierzętach, które uratowały swoich właścicieli (i swoje potomstwo) podczas pożaru ${ }^{27}$, o psach biorących czynny udział podczas wojny japońsko-chińskiej ${ }^{28}$. Informowano o wystawach ptaków $^{29}$ oraz o czynnych postawach ekologicznych w zakresie pomocy zwierzętom ${ }^{30}$,

17 Jak odbyło się święto naszych czworonożnych i skrzydlatych przyjaciót?, „Nasi Przyjaciele” 1939 (rok 3), nr 6 (czerwiec 1939), Nakładem Związku Opieki nad Zwierzętami w Krakowie, s. 4-5.

18 „Nasi Przyjaciele” 1939 (rok 3), nr 6 (czerwiec 1939), Nakładem Związku Opieki nad Zwierzętami w Krakowie, s. 5-7.

19 Ibidem, s. 8.

${ }^{20}$ Piesek szuka właściciela, „Nasi Przyjaciele” 1938 (rok 2), nr 4 (luty 1938), Nakładem Związku Opieki nad Zwierzętami w Krakowie, s. 9.

${ }^{21}$ Por. „Nasi Przyjaciele” 1938 (rok 2), nr 11 (listopad 1938), Nakładem Związku Opieki nad Zwierzętami w Krakowie, s. 8.

22 „Kronika”, „Nasi Przyjaciele” 1939 (rok 3), nr 2 (luty 1939), Nakładem Związku Opieki nad Zwierzętami w Krakowie, s. 8.

${ }^{23}$ Por. Pamiętajmy o ptakach $w$ zimie, „Nasi Przyjaciele” 1937 (rok 1), nr 1 (listopad 1937), Nakładem Związku Opieki nad Zwierzętami w Krakowie, s. 7.

${ }^{24}$ „Kronika”, „Nasi Przyjaciele” 1938 (rok 2), nr 7 (maj 1938), Nakładem Związku Opieki nad Zwierzętami w Krakowie, s. 8.

${ }^{25}$ Kalendarzyk przyrodniczy, „Nasi Przyjaciele” 1938 (rok 2), nr 5 (marzec 1938), Nakładem Związku Opieki nad Zwierzętami w Krakowie, s. 6.

${ }^{26}$ „Nasi Przyjaciele” 1938 (rok 2), nr 11 (listopad 1938), Nakładem Związku Opieki nad Zwierzętami w Krakowie, s. 1-3.

27 Por. „Kronika”, „Nasi Przyjaciele” 1939 (rok 3), nr 1 (styczeń 1939), Nakładem Związku Opieki nad Zwierzętami w Krakowie, s. 7. Por. Kronika, „Nasi Przyjaciele” 1939 (rok 3), nr 3 (marzec 1939), Nakładem Związku Opieki nad Zwierzętami w Krakowie, s. 6. Por. Kronika, „Nasi Przyjaciele” 1939 (rok 3), nr 4 (kwiecień 1939), Nakładem Związku Opieki nad Zwierzętami w Krakowie, s. 5.

28 Por. „Kronika”, „Nasi Przyjaciele” 1938 (rok 2), nr 10 (październik 1938), Nakładem Związku Opieki nad Zwierzętami w Krakowie, s. 7.

${ }^{29}$ „Kronika”, „Nasi Przyjaciele” 1939 (rok 3), nr 5 (maj 1939), Nakładem Związku Opieki nad Zwierzętami w Krakowie, s. 8.

${ }^{30}$ Egzemplifikację stanowi opisana (oraz uwieczniona na zdjęciu) pomoc kaczce i jej dzieciom w przejściu przez jezdnię, której udzielił policjant w Anglii. Por. Kronika, „Nasi Przyjaciele” 1938 (rok 2), nr 12 (grudzień 1938), Nakładem Związku Opieki nad Zwierzętami w Krakowie, s. 7. 
ciekawostkach przyrodniczych takich jak, że w leśniczówce Krępka (na Kaszubach) zimuje bocian, który swobodnie chodzi w obrębie zabudowań gospodarczych ${ }^{31}$, o nowych okazach zwierząt w zwierzyńcu Lasu Wolskiego w Krakowie ${ }^{32}$. W trosce o wychowanie ekologiczne dzieci, ich czułość wobec zwierząt, opublikowano „Prośbę konia”:

Przedktadam ci, o panie, pokorna prośbę moją:

Daj mi jeść i ugaś me pragnienie, a po pracy i trudzie dnia zaprowadź mnie do czystej stajni. Przemawiaj do mnie, ponieważ głos bardziej zachęca, niżeli wędzidło, cugle i bat.

Nie bij mnie, gdy idę pod górę i nie szarp lejcami, gdy zstępuję $w$ dót.

Jeżeli nie rozumiem od razu twego życzenia, nie spiesz się z użyciem bata, ale sprawdź stan cugli, popatrz na podkowy, czy nie rania moich nóg.

Obchodź się ze mna dobrze i naucz pracować ochotnie.

Jeżeli czasem nie chce jeść, zbadaj stan moich zębów. Nie obcinaj mi grzywy ani ogona, sq one bowiem jedyna bronia $w$ walce z muchami, które mnie prześladuja.

Kochany panie mój! Jeżeli trud i praca wielu lat uczynia mnie słabym i niezdolnym do wysitków, nie skazuj mnie na śmierć głodowa, lecz zabij mnie, bym nie cierpiał bez potrzeby.

Na koniec przebacz mi, że przychodzę do ciebie z ta pokorna prośba, ale czynię to w imieniu Iego, który także urodzit się $w$ stajence ${ }^{33}$.

\section{Konkursy dla dzieci}

$\mathrm{Na} ł a m a c h$ analizowanego czasopisma ogłaszano zadania konkursowe dla dzieci (ustalone przez Związek Opieki nad Zwierzętami w Krakowie w porozumieniu z opiekunami Kółek Młodych Przyjaciół Zwierząt w szkołach powszechnych), takie jak pisemne opracowanie następujących tematów: „Które zwierzę lubisz najbardziej i dlaczego?” „Jak udowodnisz, że jesteś przyjacielem zwierząt?” (dla dzieci z klasy IV), „Jak należy wywdzięczyć się koniowi za jego usługi oddane człowiekowi?” „Jak należy trafić do serc granatowych żołnierzy (posterunkowych), aby popierali nasze usiłowania ?" (dla dzieci z klas V) ${ }^{34}$. W grudniu 1938 r. ogłoszono następne zadania konkursowe dla członków Kółek Młodych Przyjaciół Zwierząt: „Dlaczego lubisz czytać miesięcznik 'Nasi przyjaciele’?” „W jaki sposób przekonasz swoją koleżankę i kolegę, aby został (a) członkiem Kółka Młodych Przyjaciół Zwierząt?” „Jak postąpiłbyś (postąpiłabyś), gdybyś chciał (chciała) zrobić przyjemność swojemu pieskowi?"35.

\footnotetext{
31 Por. „Nasi Przyjaciele” 1938 (rok 2), nr 11 (listopad 1938), Nakładem Związku Opieki nad Zwierzętami w Krakowie, s. 8,

32 „Kronika”, „Nasi Przyjaciele” 1939 (rok 3), nr 2 (luty 1939), Nakładem Związku Opieki nad Zwierzętami w Krakowie, s. 8.

33 „Nasi Przyjaciele” 1938 (rok 2), nr 12 (grudzień 1938), Nakładem Związku Opieki nad Zwierzętami w Krakowie, s. 4.

${ }^{34}$ Zadania konkursowe dla członków Kółek Młodych Przyjaciół Zwierząt w szkołach powszechnych, „Nasi Przyjaciele” 1937 (rok 1), nr 1 (listopad 1937), Nakładem Związku Opieki nad Zwierzętami w Krakowie, s. 8. Por. „Nasi Przyjaciele” 1937 (rok 1), nr 2 (grudzień 1937), Nakładem Związku Opieki nad Zwierzętami w Krakowie, s. 7.

35 Por. Zadania konkursowe, „Nasi Przyjaciele” 1938 (rok 2), nr 12 (grudzień 1938), Nakładem Związku Opieki nad Zwierzętami w Krakowie, s. 7-8.
} 
Najlepsze prace dzieci, które wygrały konkurs drukowano w miesięczniku „Nasi Przyjaciele"36. Opublikowano również listę 140 nazwisk uczniów szkół powszechnych, wyróżnionych za dobre opracowanie zadań konkursowych Związku Opieki nad Zwierzętami ${ }^{37}$. Ogłoszono listę nazwisk uczniów szkół powszechnych w Krakowie - Młodych Przyjaciół Zwierząt, których wyróżniono za dobre opracowanie zadań konkursowych Związku Opieki nad Zwierzętami 20 maja 1939 r. (ogółem 98 osób) ${ }^{38}$.

\section{Artykuły edukacyjne}

Na łamach miesięcznika opublikowano artykuły edukacyjne ${ }^{39}$ o ptakach ${ }^{40}$ (również przetłumaczone z języka angielskiego na język polski, za zgodą Królewskiego Towarzystwa Ochrony Zwierząt w Londynie ${ }^{41}$ ), o konieczności ich ochraniania i dokarmiania zimą $^{42}$. W miesięczniku napisano także o schroniskach dla ptaków w Anglii ${ }^{43}$ oraz

${ }^{36}$ Prace pisemne dzieci (uczniów klas IV i V szkół powszechnych), które wygrały Konkurs Młodych Przyjaciół Zwierząt (ogłoszony w listopadzie 1937 r.) opublikowano w marcu 1938 r. w: „Nasi Przyjaciele” 1938 (rok 2), nr 5 (marzec 1938), Nakładem Związku Opieki nad Zwierzętami w Krakowie, s. 2-5. Zob. również Zadania konkursowe Młodych Przyjaciół Zwierząt w odpowiedzi na ogłoszony w grudniu 1938 r. Konkurs Związku Opieki nad Zwierzętami w porozumieniu z opiekunami Kółek Młodych Przyjaciół Zwierząt (na który nadesłano 252 zadania, a opublikowano dwie nagrodzone odpowiedzi), w: „Nasi Przyjaciele” 1939 (rok 3), nr 5 (maj 1939), Nakładem Związku Opieki nad Zwierzętami w Krakowie, s. 3-6.

37 Wyróżnieni uczniowie (ogółem 140) uczęszczali do następujących szkół powszechnych w Krakowie: Szkoła nr 1 im. św. Scholastyki (6), Szkoła nr 4 im. św. Jana Kantego (23), Szkoła nr 9 im. Stanisława Konarskiego (9), Szkoła nr 12 im. Grzegorza Piramowicza (4), Szkoła nr 13 im. Adama Mickiewicza (11), Szkoła nr 14 im. Mikołaja Reja (6), Szkoła nr 17 im. Marii Konopnickiej (10), Szkoła nr 20 im. Z. Oleśnickiego (10), Szkoła nr 22 im. Jana Długosza (5), Szkoła nr 25 im. Anny Jagiellonki (9), Szkoła nr 27 im. Dąbrówki (8), Szkoła nr 28 im. Chrzanowskiej (1), Szkoła nr 29 im. Jana Matejki (4), Szkoła nr 31 im. dr. Jordana (5), Szkoła nr 34 im. Jadwigi z Łobzowa (7), Szkoła nr 37 im. św. Józefa (5), Szkoła nr 40 im. św. Stanisława (9), Szkoła nr 54 im. Munnichowej (2) oraz Szkoła Powszechna w Psarach (5) i Szkoła Powszechna w Brzegach (1). Por. Lista nazwisk Młodych Przyjaciól Zwierząt, „Nasi Przyjaciele” 1938 (rok 2), nr 8 (czerwiec 1938), Nakładem Związku Opieki nad Zwierzętami w Krakowie, s. 9.

${ }^{3}$ Lista nazwisk Młodych Przyjaciót Zwierząt, „Nasi Przyjaciele” 1939 (rok 3), nr 6 (czerwiec 1939), Nakładem Związku Opieki nad Zwierzętami w Krakowie, s. 9.

${ }^{39}$ Niektóre artykuły napisano w formie opowiadań edukacyjnych. Egzemplifikację stanowi praca S. Bełżeckiego Bóbr, „Nasi Przyjaciele” 1939 (rok 3), nr 3 (marzec 1939), Nakładem Związku Opieki nad Zwierzętami w Krakowie, s. 1-3.

${ }^{40}$ Między innymi napisano o powracających bocianach, które już w lutym 1939 r. przywędrowały do niektórych miejscowości na Wołyniu i w Wielkopolsce na swoje dawne gniazda i które dokarmiano mięsem. Por. Gdy bociany już powracaja, „Nasi Przyjaciele” 1939 (rok 3), nr 4 (kwiecień 1939), Nakładem Związku Opieki nad Zwierzętami w Krakowie, s. 4.

41 Przyjaciele rolnika, „Nasi Przyjaciele” 1937 (rok 1), nr 1 (listopad 1937), Nakładem Związku Opieki nad Zwierzętami w Krakowie, s. 2-4.

42 „Nasi Przyjaciele” 1939 (rok 3), nr 1 (styczeń 1939), Nakładem Związku Opieki nad Zwierzętami w Krakowie, s. 6.

${ }^{43}$ Szkoła latania dla ptaków, „Nasi Przyjaciele” 1937 (rok 1), nr 2 (grudzień 1937), Nakładem Związku opieki nad Zwierzętami w Krakowie, s. 5. 
o cmentarzach dla psów w Europie, Azji i w Ameryce ${ }^{44}$. Pisano o życiu zwierząt w czasie wojny ${ }^{45}$ oraz o ssakach, ptakach ${ }^{46}$, gadach, rybach, bezkręgowcach ${ }^{47}$, o znaczeniu mrówek dla siedliska życia ${ }^{48}$, cechach poszczególnych zwierząt ${ }^{49}$, a także o największym i najpiękniejszym parku leśnym w okolicy Krakowa - Lesie Wolskim ${ }^{50}$. Z okazji rocznicy urodzin - na łamach miesięcznika napisano o Adolfie Dygasińskim (1839-1902), który był miłośnikiem zwierząt, badaczem ich życia ${ }^{51}$.

\section{Opowiadania dla dzieci}

Ważną funkcję wychowawczą w procesie kształtowania postaw ekologicznych pełniły również ilustrowane fotografiami opowiadania dla dzieci o zwierzętach: Zofii KossakSzczuckiej pt. Osiołt i Papuga ${ }^{53}$, Eugenii Krzystkowej pt. Kukułka ${ }^{54}$, Stanisława Bełżeckiego (o ptaku krajów północnych) pt. Krzyżodziób $b^{55}$, O przodkach naszego konia ${ }^{56}$, Czworonożni i skrzydlaci bohaterzy (o psach i gołębiach w służbie wywiadowczej podczas wojny) ${ }^{57}$, Jak zwierzęta rozmawiaja ${ }^{58}$, Przyjaciel matp (o naukowcu, który badał

44 Por. S.Bełżecki, Psie nagrobki, „Nasi Przyjaciele” 1938 (rok 2), nr 6 (kwiecień 1938), Nakładem Związku Opieki nad Zwierzętami w Krakowie, s. 3-5.

${ }^{45}$ K. Treterowa, Jakie ustugi oddają nam zwierzęta w czasie wojny?, ,Nasi Przyjaciele” 1939 (rok 3), nr 6 (czerwiec 1939), Nakładem Związku Opieki nad Zwierzętami w Krakowie, s. 1-4.

${ }^{46}$ S. Bełżecki, Skrzydlaci architekci, „Nasi Przyjaciele” 1939 (rok 3), nr 5 (maj 1939), Nakładem Związku Opieki nad Zwierzętami w Krakowie, s. 1-3.

${ }^{47}$ S. Bełżecki, Jak długo żyja zwierzęta?, „Nasi Przyjaciele” 1938 (rok 2), nr 7 (maj 1938), Nakładem Związku Opieki nad Zwierzętami w Krakowie, s. 6.

48 „Nasi Przyjaciele” 1939 (rok 3), nr 1 (styczeń 1939), Nakładem Związku Opieki nad Zwierzętami w Krakowie, s. 5.

49 K. Gawlik, Poznajmy prawdę o zwierzętach, „Nasi Przyjaciele” 1939 (rok 3), nr 3 (marzec 1939), Nakładem Związku Opieki nad Zwierzętami w Krakowie, s. 3-4.

50 Por. „Nasi Przyjaciele” 1938 (rok 2), nr 7 (maj 1938), Nakładem Związku Opieki nad Zwierzętami w Krakowie, s. 5.

51 Wielki pisarz, który znat i kochat zwierzęta, „Nasi Przyjaciele” 1939 (rok 3), nr 4 (kwiecień 1939), Nakładem Związku Opieki nad Zwierzętami w Krakowie, s, 1.

${ }^{52}$ Z. Kossak-Szczucka, Osioł, „Nasi Przyjaciele” 1938 (rok 2), nr 3 (styczeń 1938), Nakładem Związku Opieki nad Zwierzętami w Krakowie, s. 2-3.

${ }^{53}$ Z. Kossak-Szczucka, Papuga, „Nasi Przyjaciele” 1938 (rok 2), nr 5 (marzec 1938), Nakładem Związku Opieki nad Zwierzętami w Krakowie, s. 1-2.

${ }^{54}$ E. Krzystkowa, Kukułka, „Nasi Przyjaciele” 1938 (rok 2), nr 6 (kwiecień 1938), Nakładem Związku Opieki nad Zwierzętami w Krakowie, s. 1-2.

55 S. Bełżecki, Krzyżodziób, „Nasi Przyjaciele” 1938 (rok 2), nr 3 (styczeń 1938), Nakładem Związku Opieki nad Zwierzętami, s. 3-4.

56 S. Bełżecki, O przodkach naszego konia, „Nasi Przyjaciele” 1938 (rok 2), nr 4 (luty 1938), Nakładem Związku Opieki nad Zwierzętami w Krakowie, s. 3-4.

${ }^{57}$ S. Bełżecki, Czworonożni i skrzydlaci bohaterzy, w: „Nasi Przyjaciele” 1938 (rok 2), nr 10 (październik 1938), Nakładem Związku Opieki nad Zwierzętami w Krakowie, s. 1-3.

${ }^{58}$ S. Bełżecki, Jak zwierzęta rozmawiają, „Nasi Przyjaciele” 1938 (rok 2), nr 11 (listopad 1938), Nakładem Związku Opieki nad Zwierzętami w Krakowie, s. 3-5. 
mowę tych zwierząt w amerykańskich ogrodach zoologicznych) ${ }^{59}$, o rodzinie świstaków, która żyła w Dolinie Pięciu Stawów w Tatrach (na które polowali ludzie) pt. Świstaki ${ }^{60}$, Bogdana Brzezińskiego pt. Słoń lotnikiem ${ }^{61}$, Kazio $w$ ogrodzie zoologicznym ${ }^{62}$ i Kornela Makuszyńskiego o psie Kibicu, który sprawiał kłopoty wychowawcze pt. Pan Kibic ${ }^{63}$, Wandy Jastrzębskiej o zwierzętach żyjących w Lesie Wolskim w Krakowie pt. Grymasy i zwyczaje zwierząt ${ }^{64}$, Antoniego Koziarza o lisku pt. Mykita ${ }^{65}$ oraz o $W$ zwierzecej gromadzie $^{66}$, Władysława Kurpiela pt. Moje liski (o oswojeniu dwóch małych lisków) ${ }^{67}$, Tadeusza Seweryna o chorej wiewiórce, którą wyleczyły dzieci pt. Wierusia ${ }^{68}$, Marii Czubryńskiej pt. Dżokuś zginąt (o piesku Dżokusiu i działalności Towarzystwa Opieki nad Zwierzętami) ${ }^{69}$, Arkadego Fiedlera o małpce żyjącej w Puszczy Brazylijskiej pt. Mikuś ${ }^{70}$, Ignacego Manna pt. Legendy o pekińczykach ${ }^{71}$. Niektóre z opowiadań były krótkie, ale zawsze wieńczono je wnioskiem wychowawczym, że nie można krzywdzić zwierząt ${ }^{72}$, lecz należy troszczyć się o nie ${ }^{73}$.

Należy dodać, ze na łamach miesięcznika publikowano również opowiadania napisane przez uczniów szkół powszechnych, takie jak np. Wierny przyjaciel (o psie, który

59 S. Bełżecki, Przyjaciel małp, „Nasi Przyjaciele” 1938 (rok 2), nr 12 (grudzień 1938), Nakładem Związku Opieki nad Zwierzętami w Krakowie, s. 1-3.

${ }^{60}$ S. Bełżecki, Świstaki, „Nasi Przyjaciele” 1939 (rok 3), nr 1 (styczeń 1939), Nakładem Związku Opieki nad Zwierzętami w Krakowie, s. 1-2.

${ }^{61}$ B. Brzeziński, Stoń lotnikiem, „Nasi Przyjaciele” 1938 (rok 2), nr 3 (styczeń 1938), Nakładem Związku Opieki nad Zwierzętami w Krakowie, s. 4-5.

${ }^{62}$ B. Brzeziński, Kazio w ogrodzie zoologicznym, „Nasi Przyjaciele” 1939 (rok 3), nr 2 (luty 1939), Nakładem Związku Opieki nad Zwierzętami w Krakowie, s. 5-7.

${ }^{63}$ Por. K. Makuszyński, Pan Kibic, „Nasi Przyjaciele” 1938 (rok 2), nr 4 (luty 1938), Nakładem Związku Opieki nad Zwierzętami w Krakowie, s. 1-2.

${ }^{64}$ W. Jastrzębska, Grymasy $i$ zwyczaje zwierząt, „Nasi Przyjaciele” 1938 (rok 2), nr 7 (maj 1938), Nakładem Związku Opieki nad Zwierzętami w Krakowie, s. 1-4.

${ }^{65}$ A. Koziarz, Mykita, „Nasi Przyjaciele” 1938 (rok 2), nr 8 (czerwiec 1938), Nakładem Związku Opieki nad Zwierzętami w Krakowie, s. 3-4.

${ }^{66}$ A. Koziarz, W zwierzęcej gromadzie, „Nasi Przyjaciele” 1939 (rok 3), nr 2 (luty 1939), Nakładem Związku Opieki nad Zwierzętami w Krakowie, s. 3-5.

${ }^{67}$ W. Kurpiel, Moje liski, „Nasi Przyjaciele” 1938 (rok 2), nr 10 (październik 1938), Nakładem Związku Opieki nad Zwierzętami w Krakowie, s. 4.

${ }^{68}$ T. Seweryn, Wierusia, „Nasi Przyjaciele” 1938 (rok 2), nr 8 (czerwiec 1938), Nakładem Związku Opieki nad Zwierzętami w Krakowie, s. 6-7.

${ }^{69}$ M. Czubryńska, Dżokuś zginąt, „Nasi Przyjaciele” 1938 (rok 2), nr 9 (wrzesień 1938), Nakładem Związku Opieki nad Zwierzętami w Krakowie, s. 1-5.

${ }^{70}$ A. Fiedler, Mikuś, „Nasi przyjaciele” 1939 (rok 3), nr 1 (styczeń 1939), Nakładem Związku Opieki nad Zwierzętami w Krakowie, s. 3-5.

71 I. Mann, Legendy o pekińczykach, w: „Nasi Przyjaciele” 1939 (rok 3), nr 2 (luty 1939), Nakładem Związku Opieki nad Zwierzętami w Krakowie, s. 1-3.

${ }^{72}$ Por. „Nasi Przyjaciele” 1938 (rok 2), nr 4 (luty 1938), Nakładem Związku Opieki nad Zwierzętami w Krakowie, s. 5-7.

${ }^{73}$ Co dzieci moga uczynić dla zwierząt?, „Nasi Przyjaciele” 1938 (rok 2), nr 11 (listopad 1938), Nakładem Związku Opieki nad Zwierzętami w Krakowie, s. 1-3. 
uratował swojego właściciela $)^{74}$, Szpital dla ptaszków w Szkole Powszechnej im. św. Stanisława $w$ Krakowie (poświęcony problematyce opieki nad chorymi ptakami) ${ }^{75}$, Maciek i Kaczuszki $i^{76}$.

\section{Wiersze i rozrywki umysłowe}

W miesięczniku drukowano wiersze, m.in. Witolda Zechentera pt. Najlepszy przyjaciel $^{77}$, Juliana Tuwima o psie przyjacielu pt. O moim najmilszym Dżońciu ${ }^{78}$, o kaczuszkach pt. Trudny rachunek ${ }^{79}$, Kotek ${ }^{80}$, Figielek ${ }^{81}$, Ptasie plotki ${ }^{82}$, O słoniu bez pamięci ${ }^{83}$, Spóźniony słowik ${ }^{84}$, Mieczysława Zielenkiewicza pt. Pan Doktor Dzięciot ${ }^{85}$, Mariana Hemara pt. Słownik wróbelków ${ }^{86}$. Publikowano również wiersze napisane przez uczniów szkół powszechnych ${ }^{87}$. W osobnym dziale miesięcznika systematycznie umieszczano re-

${ }^{74}$ M. Maciukiewicz (uczeń kl. VII Szkoły Powszechnej im. św. Jana Kantego w Krakowie), Wierny przyjaciel, „Nasi Przyjaciele” 1937 (rok 1), nr 2 (grudzień 1937), Nakładem Związku Opieki nad Zwierzętami w Krakowie, s. 5.

${ }^{75}$ M. Ruszkiewicz (uczennica kl. V Szkoły Powszechnej nr 40 im. św. Stanisława w Krakowie), Szpital dla ptaszków w Szkole Powszechnej im. św. Stanisława w Krakowie, „Nasi Przyjaciele” 1938 (rok 2), nr 5 (marzec 1938), Nakładem Związku Opieki nad Zwierzętami w Krakowie, s. 5-6.

${ }^{76}$ Opowiadanie napisał John New - 12 letni chłopiec, który był członkiem Kółka Młodych Przyjaciół Zwierząt w Londynie, a jego opowiadanie - w lutym 1938 r. - opublikowano w miesięczniku „Animal Ways”, który jest organem wszystkich Kółek Młodych Przyjaciół Zwierząt w Anglii, „Nasi Przyjaciele” 1938 (rok 2), nr 11 (listopad 1938), Nakładem Związku Opieki nad Zwierzętami w Krakowie, s. 5-6.

77 „Nasi Przyjaciele” 1937 (rok 1), nr 1 (listopad 1937), Nakładem Związku Opieki nad Zwierzętami w Krakowie, s. 4.

78 „Nasi Przyjaciele” 1937 (rok 1), nr 2 (grudzień 1937), Nakładem Związku Opieki nad Zwierzętami w Krakowie, s. 2.

79 „Nasi Przyjaciele” 1938 (rok 2), nr 4 (luty 1938), Nakładem Związku Opieki nad Zwierzętami w Krakowie, s. 5.

${ }^{80}$ „Nasi Przyjaciele” 1938 (rok 2), nr 5 (marzec 1938), Nakładem Związku Opieki nad Zwierzętami w Krakowie, s. 2.

${ }^{81}$ „Nasi Przyjaciele” 1938 (rok 2), nr 7 (maj 1938), Nakładem Związku Opieki nad Zwierzętami w Krakowie, s. 4.

82 „Nasi Przyjaciele” 1938 (rok 2), nr 10 (październik 1938), Nakładem Związku Opieki nad Zwierzętami w Krakowie, s. 5.

83 „Nasi Przyjaciele” 1938 (rok 2), nr 11 (listopad 1938), Nakładem Związku Opieki nad Zwierzętami w Krakowie, s. 6-7.

${ }^{84}$ „Nasi Przyjaciele” 1939 (rok 3), nr 4 (kwiecień 1939), Nakładem Związku Opieki nad Zwierzętami w Krakowie, s. 6.

85 „Nasi Przyjaciele” 1938 (rok 2), nr 6 (kwiecień 1938), Nakładem Związku Opieki nad Zwierzętami w Krakowie, s. 5.

${ }^{86}$ „Nasi Przyjaciele” 1939 (rok 3), nr 3 (marzec 1939), Nakładem Związku Opieki nad Zwierzętami w Krakowie, s. 5.

${ }^{87}$ F. Kachan (uczennica kl. IVb Szkoły Powszechnej im. M. Konopnickiej w Krakowie) wiersz pt. Wiewiórki, „Nasi Przyjaciele” 1938 (rok 2), nr 3 (styczeń 1938), Nakładem Związku Opieki nad Zwierzętami w Krakowie, s. 6; H. Sobel (uczennica kl. IVa Szkoły Powszechnej im. Marii Konopnickiej w Krakowie) 
busy $^{88}$ i łamigłówki przyrodnicze (logogryfy ${ }^{89}$, szarady), zagadki ${ }^{90}$. Egzemplifikację stanowią łamigłówki ułożone przez Bogdana Przewłockiego ${ }^{91}$ (ucznia klasy VIa Szkoły Powszechnej im. św. Jana Kantego w Krakowie), w jednej z nich środkowy rząd liter daje rozwiązanie - jest nim hasło propagujące miłość do zwierząt domowych ${ }^{92}$. Dobry przykład stanowi również łamigłówka ułożona przez Bernarda Grunhanta (ucznia kl. V Szkoły Powszechnej im. św. Jana Kantego w Krakowie), której rozwiązaniem jest hasło „Nie bijcie zwierząt"93 oraz rebus ułożony przez Zbigniewa Kostucha (ucznia kl. VIb Szkoły Powszechnej nr 4 im. św. Jana Kantego w Krakowie) ${ }^{94}$, a także logogryf ułożony

wiersz pt. Kotek - to nie koń, „Nasi Przyjaciele” 1938 (rok 2), nr 4 (luty 1938), Nakładem Związku Opieki nad Zwierzętami w Krakowie, s. 2; B. Nowowiejska (uczennica kl. V Szkoły Powszechnej nr 37 im. św. Józefa w Krakowie) wiersz pt. Wiewióreczka oraz I. Płazakówna (uczennica kl. IV Szkoły Powszechnej nr 20 im. Z. Oleśnickiego w Krakowie) wiersz pt. Co robia kotki, „Nasi Przyjaciele” 1938 (rok 2), nr 8 (czerwiec 1938), Nakładem Związku Opieki nad Zwierzętami w Krakowie, s. 5; H. Schartówna (uczennica kl. IV Szkoły Powszechnej nr 13 im. Adama Mickiewicza w Krakowie) wiersz pt. Moje kanarki, „Nasi Przyjaciele” 1938 (rok 2), nr 8 (czerwiec 1938), Nakładem Związku Opieki nad Zwierzętami w Krakowie, s. 8; T. Mikucka (uczennica kl. Va Szkoły Powszechnej nr 1 im. św. Scholastyki) wierszyk pt. Jesień, „Nasi Przyjaciele” 1938 (rok 2), nr 9 (wrzesień 1938), Nakładem Związku Opieki nad Zwierzętami w Krakowie, s. 5; B. Schicho (uczennica kl. IV Szkoły Powszechnej nr 27 im. Dąbrówki w Krakowie) wiersz pt. Wdzięczny kotek, „Nasi Przyjaciele" 1938 (rok 2), nr 10 (październik 1938), Nakładem Związku Opieki nad Zwierzętami w Krakowie, s. 7; B. Nowowiejska (uczennica kl. VI Szkoły Powszechnej nr 37 im. św. Józefa w Krakowie) wiersz pt. Ptaszki w zimie, „Nasi Przyjaciele” 1938 (rok 2), nr 12 (grudzień 1938), Nakładem Związku Opieki nad Zwierzętami w Krakowie, s. 6; Z. Torbińska (uczennica Szkoły Powszechnej nr 4 w Legionowie-Przystanek) wiersz pt. Cicho Ciapusiu, „Nasi Przyjaciele” 1939 (rok 3), nr 2 (luty 1939), Nakładem Związku Opieki nad Zwierzętami w Krakowie, s. 8; Z. Torbińska (uczennica Szkoły Powszechnej nr 4 w Legionowie-Przystanek) wiersz pt. Niegrzeczny Pikuś, „Nasi Przyjaciele” 1939 (rok 3), nr 3 (marzec 1939), Nakładem Związku Opieki nad Zwierzętami w Krakowie, s. 7; J. Czarnuchowska (uczennica kl. Va Szkoły Powszechnej im. Zbigniewa Oleśnickiego w Krakowie) wiersz o małym piesku pt. Figa, „Nasi Przyjaciele” 1939 (rok 3), nr 4 (kwiecień 1939), Nakładem Związku Opieki nad Zwierzętami w Krakowie, s. 6; B. Nowowiejska (uczennica kl. VI Szkoły Powszechnej nr 37 im. św. Józefa w Krakowie) wiersz pt. W obronie koni, „Nasi Przyjaciele” 1939 (rok 3), nr 5 (maj 1939), Nakładem Związku Opieki nad Zwierzętami w Krakowie, s. 6.

88 „Nasi Przyjaciele” 1938 (rok 2), nr 4 (luty 1938), Nakładem Związku Opieki nad Zwierzętami w Krakowie, s. 8. Por. „Nasi Przyjaciele” 1938 (rok 2), nr 11 (listopad 1938), Nakładem Związku Opieki nad Zwierzętami w Krakowie, s. 8. Por. „Nasi Przyjaciele” 1938 (rok 2), nr 12 (grudzień 1938), Nakładem Związku Opieki nad Zwierzętami w Krakowie, s. 8. Por. „Nasi Przyjaciele” 1939 (rok 3), nr 1 (styczeń 1939), Nakładem Związku Opieki nad Zwierzętami w Krakowie, s. 8. Por. „Nasi Przyjaciele” 1939 (rok 3), nr 4 (kwiecień 1939), Nakładem Związku Opieki nad Zwierzętami w Krakowie, s. 8.

89 „Nasi Przyjaciele” 1939 (rok 3), nr 3 (marzec 1939), Nakładem Związku Opieki nad Zwierzętami w Krakowie, s. 8. Por. „Nasi Przyjaciele” 1939 (rok 3), nr 5 (maj 1939), Nakładem Związku Opieki nad Zwierzętami w Krakowie, s. 8.

${ }^{0}$ Zagadki, „Nasi Przyjaciele” 1939 (rok 3), nr 2 (luty 1939), Nakładem Związku Opieki nad Zwierzętami w Krakowie, s. 8.

${ }^{91}$ Rozrywki umysłowe, „Nasi Przyjaciele” 1938 (rok 2), nr 6 (kwiecień 1938), Nakładem Związku Opieki nad Zwierzętami w Krakowie, s. 8.

${ }_{92}$ Por. „Nasi Przyjaciele” 1937 (rok 1), nr 1 (listopad 1937), Nakładem Związku Opieki nad Zwierzętami w Krakowie, s. 8. Por. Rozrywki umysłowe, „Nasi Przyjaciele” 1937 (rok 1), nr 2 (grudzień 1937), Nakładem Związku Opieki nad Zwierzętami w Krakowie, s. 7-8.

${ }_{93}$ Por. Rozrywki umysłowe, „Nasi Przyjaciele” 1938 (rok 2), nr 3 (styczeń 1938), Nakładem Związku Opieki nad Zwierzętami w Krakowie, s. 8.

${ }^{94}$ Rozrywki umysłowe, „Nasi Przyjaciele” 1938 (rok 2), nr 7 (maj 1938), Nakładem Związku Opieki nad Zwierzętami w Krakowie, s. 8. 
przez Tadeusza Wojskiego (ucznia kl. V Szkoły Powszechnej nr 4 im. Jana Kantego w Krakowie) ${ }^{95}$ i rozsypanka ułożona przez Ignacego Lanza (ucznia kl. IV Szkoły Powszechnej nr 4 im. św. Jana Kantego w Krakowie) ${ }^{96}$.

\section{Inne działy miesięcznika $w$ trosce o postawy ekologiczne dzieci}

W miesięczniku umieszczano ilustracje o tematyce przyrodniczej oraz skrzynek dla ptaków ${ }^{97}$, opublikowano zdjęcie z Pochodu Młodych Przyjaciół Zwierząt w Krakowie podczas „Dnia Dobroci dla Zwierząt” (11 października 1936 r.) ${ }^{98}$, hasła dotyczące ochrony przyrody (np. „Niszczmy sidła i potrzaski”, „Nie więźmy nigdy dzikich ptaków”), apele do dzieci na wsi, aby roztoczyły troskliwą opiekę nad psami podwórkowymi (uszczelniły psią budę przed zimnem, wkładały świeżą podściółkę, systematycznie je karmiły) i nie krzywdziły ptaków ${ }^{99}$. Apelowano również do dzieci wyjeżdżających na wakacje na wieś, aby pamiętały, że największym cierpieniem psa jest brak wody w czasie upałów: „Pamiętajmy o psach łańcuchowych!”100. Redakcja miesięcznika „Nasi Przyjaciele" opublikowała list, napisany przez ucznia szkoły powszechnej, który będąc przyjacielem dzikich ptaków, zwrócił się w nim z apelem, aby ich nie więzić ${ }^{101}$. Ponadto publikowano spisy audycji radiowych dla dzieci o tematyce przyrodniczo-środowiskowej $^{102}$.

Redakcja miesięcznika „Nasi Przyjaciele” prowadziła korespondencję ze swoimi czytelnikami, odpowiadała na pytania dzieci szkół powszechnych ${ }^{103}$, dotyczące opieki nad

${ }^{95}$ Rozrywki umysłowe, „Nasi Przyjaciele” 1938 (rok 2), nr 8 (czerwiec 1938), Nakładem Związku Opieki nad Zwierzętami w Krakowie, s. 8.

96 Rozrywki umysłowe, „Nasi Przyjaciele” 1938 (rok 2), nr 9 (wrzesień 1938), Nakładem Związku Opieki nad Zwierzętami w Krakowie, s. 8.

97 „Nasi Przyjaciele” 1938 (rok 2), nr 7 (maj 1938), Nakładem Związku Opieki nad Zwierzętami w Krakowie, s. 5.

98 „Nasi Przyjaciele” 1938 (rok 2), nr 9 (wrzesień 1938), Nakładem Związku Opieki nad Zwierzętami w Krakowie, s. 4.

99 Por. Apel do dzieci na wsi, „Nasi Przyjaciele” 1938 (rok 2), nr 3 (styczeń 1938), Nakładem Związku Opieki nad Zwierzętami w Krakowie, s. 6.

100 „Nasi Przyjaciele” 1938 (rok 2), nr 8 (czerwiec 1938), Nakładem Związku Opieki nad Zwierzętami w Krakowie, s. 7. Por. Apel do dzieci pt. Gdy nadchodza wakacje, „Nasi Przyjaciele” 1939 (rok 3), nr 6 (czerwiec 1939), Nakładem Związku Opieki nad Zwierzętami w Krakowie, s. 5.

101 Por. „Nasi Przyjaciele” 1938 (rok 2), nr 8 (czerwiec 1938), Nakładem Związku Opieki nad Zwierzętami w Krakowie, s. 5.

102 Warto postuchać! Program audycji radiowych dla dzieci na miesiąc kwiecień, „Nasi Przyjaciele” 1938 (rok 2), nr 6 (kwiecień 1938), Nakładem Związku Opieki nad Zwierzętami w Krakowie, s. 7-8. Por. Warto postuchać! Program audycyj radiowych dla dzieci na miesiąc maj, „Nasi Przyjaciele” 1938 (rok 2), nr 7 (maj 1938), Nakładem Związku Opieki nad Zwierzętami w Krakowie, s. 8. Por. „Nasi Przyjaciele” 1939 (rok 3), nr 5 (maj 1939), Nakładem Związku Opieki nad Zwierzętami w Krakowie, s. 7.

103 „Nasi Przyjaciele” 1938 (rok 2), nr 4 (luty 1938), Nakładem Związku Opieki nad Zwierzętami w Krakowie, s. 7-8. Por. Skrzynka pocztowa, „Nasi Przyjaciele” 1938 (rok 2), nr 7 (maj 1938), Nakładem Związku Opieki nad Zwierzętami w Krakowie, s. 7. Por. Skrzynka pocztowa, „Nasi Przyjaciele” 1938 (rok 2), nr 10 
zwierzętami ${ }^{104}$. Publikowano również interesujące informacje otrzymane od dzieci, które pisały o swoich czynnych postawach ekologicznych ${ }^{105} \mathrm{~W}$ zakresie opieki nad bezdomnymi zwierzętami ${ }^{106}$. Udzielano szereg wskazówek pomocnych $\mathrm{w}$ procesie hodowania rybek $\mathrm{w}$ akwarium ${ }^{107}$ oraz ratowania chorych zwierząt ${ }^{108}$, korespondowano z członkami Kółek Młodych Przyjaciół Zwierząt ${ }^{109}$.

Na wewnętrznej stronie okładki miesięcznika „Nasi Przyjaciele” umieszczano spisy książek przyrodniczych dla dzieci, wydanych przez Książnicę-Atlas ${ }^{110}$. Wśród nich są znane dzieła J. H. Fabre (Nasi sprzymierzeńcy, Szkodniki, Z życia owadów), W. Haberkantówny (Śmietnik), W. Szafera (Yellowstone) $)^{111}$.

\section{Wnioski}

Na podstawie przeprowadzonych badań (kryterium problemowe) stwierdzono, że wydawany w latach 1937-1939 miesięcznik „Nasi Przyjaciele” pełnił ważną rolę dydaktyczno-wychowawczą w kształtowaniu postaw ekologicznych uczniów szkół powszechnych. W poszczególnych działach periodyku systematycznie prowadzono kronikę, publikowano zadania konkursowe dla dzieci, artykuły edukacyjne, opowiadania dla dzieci, wiersze znanych polskich poetów, zdjęcia flory i fauny, ilustracje o tematyce przyrod-

(październik 1938), Nakładem Związku Opieki nad Zwierzętami w Krakowie, s. 8. Por. Skrzynka pocztowa, „Nasi Przyjaciele” 1938 (rok 2), nr 11 (listopad 1938), Nakładem Związku Opieki nad Zwierzętami w Krakowie, s. 8. Por. Skrzynka pocztowa, „Nasi przyjaciele” 1938 (rok 2), nr 12 (grudzień 1938), Nakładem Związku Opieki nad Zwierzętami w Krakowie, s. 6. Por. Skrzynka pocztowa, „Nasi Przyjaciele” 1939 (rok 3), nr 2 (luty 1939), Nakładem Związku Opieki nad Zwierzętami w Krakowie, s. 7. Por. Skrzynka pocztowa, „Nasi Przyjaciele" 1939 (rok 3), nr 4 (kwiecień 1939), Nakładem Związku Opieki nad Zwierzętami w Krakowie, s. 7-8. Por. Skrzynka pocztowa, „Nasi Przyjaciele” 1939 (rok 3), nr 5 (maj 1939), Nakładem Związku Opieki nad Zwierzętami w Krakowie, s. 7. Por. Skrzynka pocztowa, „Nasi Przyjaciele” 1939 (rok 3), nr 6 (czerwiec 1939), Nakładem Związku Opieki nad Zwierzętami w Krakowie, s. 7-8.

104 Skrzynka pocztowa, „Nasi Przyjaciele” 1939 (rok 3), nr 1 (styczeń 1939), Nakładem Związku Opieki nad Zwierzętami w Krakowie, s. 6-7. Por. Skrzynka pocztowa, „Nasi Przyjaciele” 1939 (rok 3), nr 3 (marzec 1939), Nakładem Związku Opieki nad Zwierzętami w Krakowie, s. 5.

105 „Nasi Przyjaciele” 1938 (rok 2), nr 6 (kwiecień 1938), Nakładem Związku Opieki nad Zwierzętami w Krakowie, s. 6-7.

${ }^{106}$ Co robia dla zwierząt ich przyjaciele w Ostrówku, „Nasi Przyjaciele” 1939 (rok 3), nr 5 (maj 1939), Nakładem Związku Opieki nad Zwierzętami w Krakowie, s. 7.

107 Por. Skrzynka pocztowa, „Nasi Przyjaciele” 1937 (rok 1), nr 2 (grudzień 1937), Nakładem Związku Opieki nad Zwierzętami w Krakowie, s. 6-7.

108 Skrzynka pocztowa, „Nasi Przyjaciele” 1938 (rok 2), nr 3 (styczeń 1938), Nakładem Opieki nad Zwierzętami w Krakowie, s. 7. Por. Skrzynka pocztowa, „Nasi Przyjaciele” 1938 (rok 2), nr 8 (czerwiec 1938), Nakładem Związku Opieki nad Zwierzętami w Krakowie, s. 8. Por. Skrzynka pocztowa, „Nasi Przyjaciele” 1938 (rok 2), nr 9 (wrzesień 1938), Nakładem Związku Opieki nad Zwierzętami w Krakowie, s. 7.

109 Por. Skrzynka pocztowa, „Nasi Przyjaciele” 1938 (rok 2), nr 5 (marzec 1938), Nakładem Związku Opieki nad Zwierzętami w Krakowie, s. 7-8.

110 KSIĄŻNICA-ATLAS Lwów (Czarnieckiego 12) Warszawa (Nowy Świat 59).

111 „Nasi Przyjaciele” 1938 (rok 2), nr 3 (styczeń 1938), Nakładem Związku Opieki nad Zwierzętami w Krakowie, s. 8. 
niczej, a także hasła i apele dotyczące ochrony przyrody. W miesięczniku umieszczono również spisy audycji radiowych oraz spisy książek dla dzieci, prowadzono korespondencję z uczniami szkół powszechnych i członkami Kółek Młodych Przyjaciół Zwierząt. Było to zgodne, po pierwsze - z kulturowymi uwarunkowaniami edukacji ekologicznej w Drugiej Rzeczypospolitej; po wtóre - z zarządzeniami Ministerstwa Wyznań Religijnych i Oświecenia Publicznego, które sprawowało nadzór nad realizacją idei ochrony przyrody i edukacji ekologicznej w Polsce w latach 1918-1939; po trzecie - z systemowym ujęciem edukacji ekologicznej w programach, rozkładach nauczania dla szkół powszechnych w Drugiej Rzeczypospolitej oraz środkami dydaktycznymi stosowanymi $\mathrm{w}$ procesie edukacji ekologicznej w omawianym okresie historycznym.

Należy dodać, że edukacja ekologiczna w Drugiej Rzeczypospolitej stanowi wartość aplikacyjną dla edukacji ekologicznej w III Rzeczypospolitej, cenne dziedzictwo kultury narodowej, antecedencję edukacji ekologicznej w 2 poł. XX w. i na pocz. XXI w., zwłaszcza po wdrożeniu reformy edukacyjnej w 1999 r. Dzięki reformie polskiego systemu szkolnictwa edukacja ekologiczna jest realizowana na wszystkich etapach procesu dydaktyczno-wychowawczego ${ }^{112}$. Można więc mieć nadzieję, że dziedzictwo kultury ideacyjnej, normatywnej w zakresie edukacji ekologicznej Drugiej Rzeczypospolitej będzie twórczo ewokowało w ogólnej tendencji kultury ponowoczesnej i stanowiło twórczą inspirację dla praktyki edukacyjnej w XXI w.

\section{Bibliografia}

Źródła drukowane

Dziennik Urzędowy Ministerstwa Wyznań Religijnych i Oświecenia Publicznego, Warszawa 1939, poz. 340.

„Nasi Przyjaciele”, Nakładem Związku Opieki nad Zwierzętami w Krakowie (1937-1939).

\footnotetext{
poz. 625 .

112 Por. Podstawa programowa kształcenia ogólnego, w: Dz. U. Nr 61 z dnia 19 czerwca 2001 r.,
} 
